\title{
PROTEOMIC INSIGHT INTO THE MOLECULAR PRINCIPLES OF GRAPEVINE HABITUATION
}

\author{
MÁRIA ČARNÁi, ${ }^{1,2}$ VLADIMÍR REPKA ${ }^{1}$, ERNEST ŠTURDÍK² \\ 'Plant Production Research Center Piešt'any \\ ${ }^{2}$ Slovak University of Technology Bratislava
}

ČARNÁ, M. - REPKA, V. - ŠTURDÍK, E.: Proteomic insight into the molecular principles of grapevine habituation. Agriculture (Polnohospodárstvo), vol. 57, 2011, no. 4, pp. 129-136.

\footnotetext{
Two-dimensional gel electrophoresis coupled to protein microarray analysis was used to examine, for the first time, the molecular mechanisms of grapevine (Vitis vinifera L., cv. Limberger) habituation. The examination of 2-D maps derived from control and habituated cell culture revealed the presence of 55 protein spots displaying a differential expression pattern. These facts have provide a molecular evidence suggesting that the habituated cells can be used as a model for study of cell dif-
}

ferentiation and plant defense mechanisms. Cell death, extracellular alkalinization and expression of genes responsible for the formation of the defense-related proteins were analyzed in suspension cultures with hormonal autonomy (habituation). Results obtained using habituated grapevine cells compared with non-habituated cells were different and strongly depended on the concentration of elicitor applied.

Key words: habituation, Vitis vinifera L., elicitor, enzyme activity, proteome profiling

Plant cells and tissues, which are propagated in axenic culture, sometimes lose their exogenous requirement for certain growth factors. This type of cellular, heritable change is known as habituation (Meins 1982). They may be subcultured in the absence of the added factors, auxins and cytokinins and certain vitamins. Comparison of the properties of habituated and nonhabituated cells leads to the conclusion that habituation is a form of neoplastic transformation involving heritable changes in cell phenotype that can result in autonomous growth (Meins 1989).

At present, experimental evidence for the mechanism of habituation is obscure. One approach towards the identification of the mechanism of habituation is a comparison of gene expression pattern in habituated and non-habituated cell cultures (Repka \& Baumgartnerová 2008). Moreover, the availability of genomic sequence data allows us to conduct comparative genomic studies, yielding important information on developmental processes and disease defense mechanisms (Rubin et al. 2000; Eichler \& Sankoff 2003). Protein comparison using proteomes alone is, however, not fully sufficient to understand how the cellular machinery evolved over a long period of time. A step forward would be to look at all the interactions among them. An interactome is a whole set of molecular interactions in a cell. Because the interactome considers the whole organism, there is a need to collect a massive amount of information. These studies may help to clarify the molecular mechanisms of defense responses and also of neoplastic phenomena in plants (Repka 2006).

A pathogen must be able to recognize the presence of their host plant in the environment and often the specific surface for successful infection. To date,

Ing. Mária Čarná, RNDr. Vladimír Repka, CSc., Plant Production Research Center Piešt’any - Research Institute of Viticulture and Enology, 83101 Bratislava, Matúšková 25, Slovak Republic. E-mail: carna@vurv.sk, repka@vurv.sk Ing. Mária Čarná, doc. Ing. Ernest Šturdík, CSc., Slovak University of Technology in Bratislava, Faculty of Chemical and Food Technology, 81237 Bratislava, Radlinského 9, Slovak Republic. E-mail: maria.carna@stuba.sk, ernest.sturdik@stuba.sk 
mechanisms of defense responses in grapevine are not almost understood. Therefore, it is a good idea to compare habituated and non-habituated cultures to clarify the process of various signalling cascades, which start after the penetration of pathogen through the cell surface. This was a reason why we worked with exogenous methyl jasmonate (MeJA), which is an effective trigger of defense responses (Repka 2006). It has been demonstrated, that MeJA is a strong trigger of grapevine defense mechanisms (Repka et al. 2000; Dubery et al. 2000). This elicitor induced a hypersensitive response associated with an oxidative burst resulting in the production of reactive oxygen species.

The production and removal of extracellular reactive oxygen species (ROS) in plants may be mediated by the activity of enzymes located in the plasma membrane or/and in the apoplast. The main enzymatic sources of ROS production at the plant cell surface are still unknown, but most results point to two mechanisms, one involving the action of peroxidases. Polyphenol oxidase (PPO), also known as catechol oxidase, is a copper-containing enzyme catalyzing the oxidation of o-diphenols to o-diquinones. These quinones polymerize to form brown pigments associated with browning in plants (Bostock 2005). The physiological function of PPO is as yet unknown, although it has been associated with disease resistance. The defensive role of PPO against leaf-eating insects has been proposed in particular, and is well documented (Felton et al. 1999). PPOs are defense-related proteins whose activities are most intensively induced in tomato plants submitted to either wounding and/or to methyl jasmonate (MeJA) vapour treatment (Constabel et al. 1995). A strong induction of PPO by wounding was also observed in tobacco (Nicotiana tabacum L.) and hybrid poplar (Populus trichocarpa $x$ deltoides; Constabel \& Ryan 1998).

In our contribution we examined changes of proteome profiles in hormonally habituated grapevine cells. These studies may help to clarify the molecular mechanisms of neoplastic phenomena in plants and perhaps in animals.

\section{MATERIAL AND METHODS}

\section{Plant material}

Long-term cultivated callus cultures of grapevine
(Vitis vinifera L., cv. Limberger) were used for all experiments. These cultures were maintained under controlled environmental conditions at $25^{\circ} \mathrm{C}, 80 \%$ relative humidity, a photon flux density of $80 \mu \mathrm{mol} \mathrm{m} \mathrm{m}^{-1} \mathrm{~s}^{-1}$ and $16 / 8 \mathrm{~h}$ photoperiod as described elsewhere (Repka 2006).

\section{Habituation experiment}

Sucrose, Gamborg B5 vitamins (Gamborg et al. 1968), auxin (1 mg ml-1 1-naphthylacetic acid) and cytokinin (1 $\mathrm{mg} \mathrm{ml}^{-1}$ 6-benzylaminopurine) were incorporated in MS (Murashige \& Skoog 1962) media at different concentrations and grapevine calli were cultivated on these media for a period of $60 \mathrm{~d}$. The experiments were then terminated, fresh weights were recorded and tissues were frozen for proteome analysis.

Protein expression profiling and comparative interactomics

2-D PAGE profiling used gels, which were fixed and silver stained according to the protocol of Rabilloud et al. (1992). Digitized images were obtained using the Kodak Images station $2000 \mathrm{R}$ at $60.5 \mathrm{~nm}$ resolution and analyzed with the software tools included. Proteomics-based identification using high-throughput microarrays, as well as the immunodetection of specific antigens, were conducted basically according to Repka (2006). To analyze protein-protein interaction networks, a threshold-free functional profiling analysis was performed within and among complete genomes, such as yeast, fly, worm, Arabidopsis and human, and their HTP maps.

\section{Assay of enzymatic activity}

Extracts of the samples were prepared for the analyses by homogenizing $3 \mathrm{~g}$ of callus fresh weight in $3 \mathrm{ml}$ of ice cold TRISEPAC buffer $\left(50 \mathrm{mmol} \mathrm{dm}^{-3}\right.$ Tris- $\mathrm{HCl}$, $\mathrm{pH} 8.0,500 \mathrm{mmol} \mathrm{dm}^{-3}$ sucrose, $1 \mathrm{mmol} \mathrm{dm}^{-3}$ EDTA,

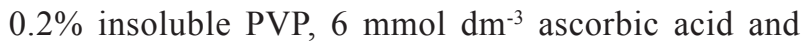
$0.1 \%$ cystein). The extracts were centrifuged at 15,000 $g$ for $10 \mathrm{~min}$ at $4^{\circ} \mathrm{C}$. The supernatant was collected and protein content was determined according to Bradford (1976) using bovine serum albumin as a standard.

PPO activity was determined by measuring the increase in absorbance at $494 \mathrm{~nm}$ with a recording spectrophotometer Epoch (Biotek Instruments, USA). The reaction mixture contained $10 \mathrm{mmol} \mathrm{dm}^{-3}$ 4-methyl-

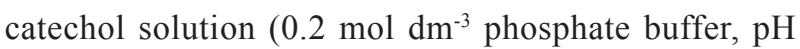
6.3 ). The reaction was initiated by addition of enzyme 
extract. The blank sample contained only the 4-methylcatechol solution. The enzyme activity was calculated from the linear portion of the curve (Wong et al. 1971). One unit of PPO activity was defined as the amount of enzyme, which caused an increase in absorbance of $0.001 \mathrm{~min}^{-1}$.

\section{Cell suspension treatment}

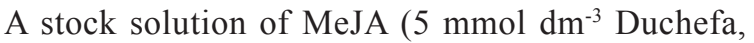
Haarlem, The Netherlands) was first made up in ethanol $(96 \%)$, various concentrations of $\operatorname{MeJA}(0.5,5$, $50 \mu \mathrm{mol} \mathrm{dm}^{-3}$ ) were prepared by appropriate dilution in water and adjusted to the final concentration with $1 \%$ ethanol in cells suspension.

\section{Analysis of cell death}

To determine changes in plant cell viability, cell cultures were incubated after treatment with MeJA for 15 min with $0.05 \%$ Evans blue (Sigma, Deisenhofen,
Germany) and then washed extensively to remove the excess and unbound dye. Dye bound to dead cells was solubilised in 50\% methanol with $1 \%$ SDS for $30 \mathrm{~min}$ at $50^{\circ} \mathrm{C}$ and quantified by absorbance according to Repka (2001).

\section{Alkalinization response}

To measure alkalinization of the growth medium, $20 \mathrm{ml}$ aliquots of grapevine cell suspensions ( $5 \mathrm{~g}$ fresh weigh) were equilibrated in open vials for 20, $30 \mathrm{~min}$ with slow continuous stirring until a steady $\mathrm{pH}$ value was reached. Upon treatment the cells with MeJA, the extracellular $\mathrm{pH}$ was monitored with a combined glass electrode in the medium while stirring. The $\mathrm{pH}$ of the growth medium was continuously measured every two minutes for a period of $60 \mathrm{~min}$.

\section{Statistical analysis}

Data presented are mean values \pm S.E.M (Standard

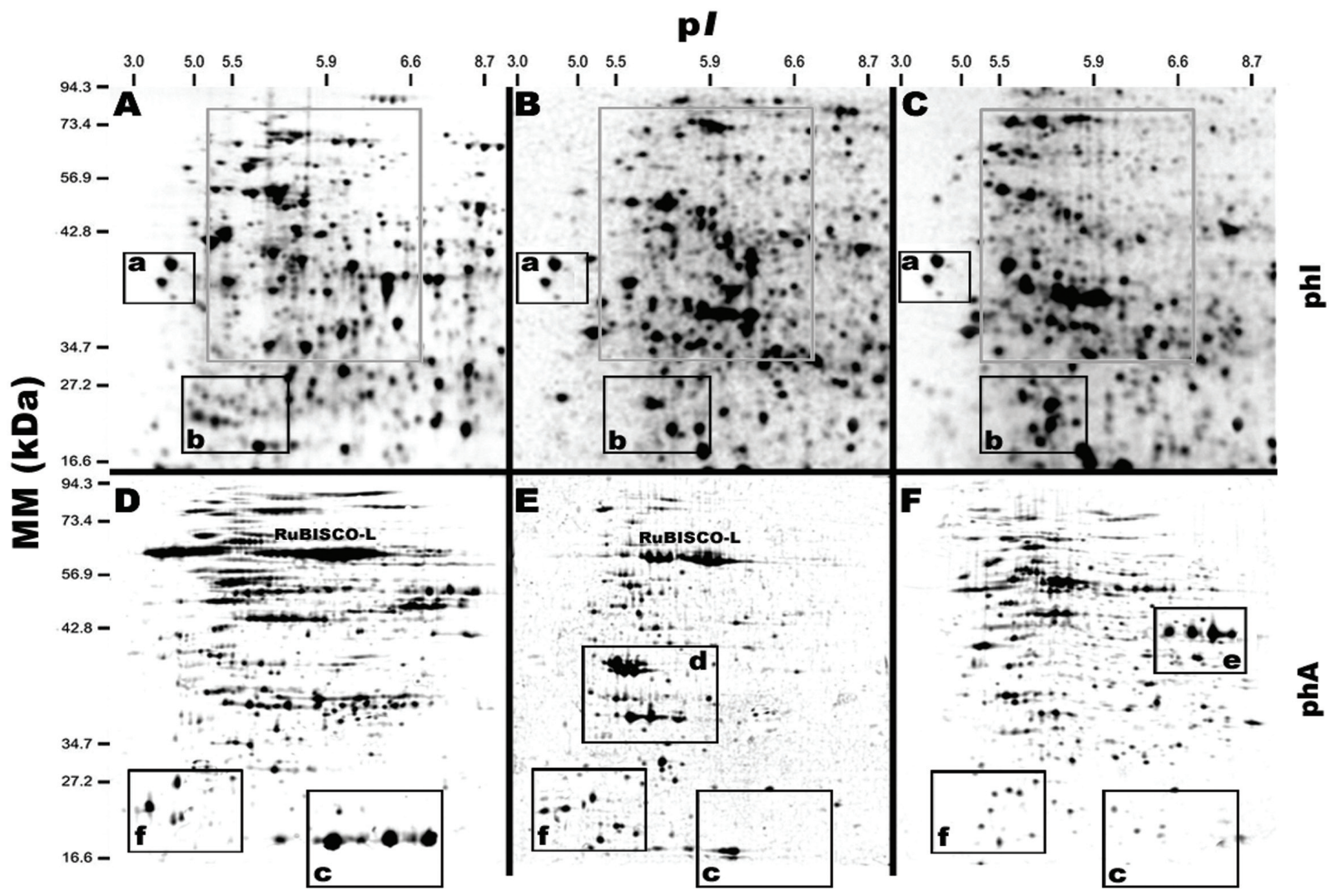

Fig.1. Representative 2-D gels visualizing proteins from $\mathrm{PhI}$ and $\mathrm{PhA}$ calluses either for cytokinin (B, E) or auxin (C, F) compared to control proteome maps (A, D). The first dimension was focused across a 3 to $10 \mathrm{pH}$ unit range and the second electrophoretic dimensions resolved proteins between 10 and $20 \mathrm{kDa}$. An equal amount $(150 \mu \mathrm{g})$ of total protein extracts was loaded in each gel 
Error of the Mean) for three replicates. For analytical and/or preparative separation 2-D PAGE profiling was performed and the reproducibility of these profiles was confirmed by carrying out two independent experiments.

\section{RESULTS AND DISCUSSION}

\section{Proteome profiling}

The high-resolution 2-D maps, which were used for visualizing protein patterns, displayed up to 2,500 spots from control, auxin-, and cytokinin-habituated samples. Figures $1 \mathrm{~A}-\mathrm{C}$ represent protein patterns obtained from $\mathrm{PhI}$ (photosynthetically inactive) calli and the Figures 1 D-F show the different content of PhA (photosynthetically active) patterns. The comparison of habituated $\mathrm{PhA}$ and $\mathrm{PhI}$ cultures demonstrated in Figure 1, displays enormous difference of expression patterns for cytokinin- and auxin-habituated calli (Fig. $1 \mathrm{~B}, \mathrm{E}$ and Fig. $1 \mathrm{C}, \mathrm{F}$ ) compared with the control (Fig. $1 \mathrm{~A}, \mathrm{D})$. The number of up-regulated spots largely exceeded that of down-regulated ones. Altered expression pattern was demonstrated in 55 proteins due to the different metabolic state of both types of callus cultures. Figures $1 \mathrm{~B}$ and E, representing callus cultures habituated for the cytokinin compound, show extensively changed protein patterns that substantially differ from their control counterparts and/or auxin-habituated calli. Proteome changes of auxine-habituated culture (Fig $1 \mathrm{C}$ and F) were also different in many points from those of control and/or cytokinin-habituated ones. Two prominent spots in $\mathrm{PhI}$ calluses (Fig. $1 \mathrm{~A}-\mathrm{C}$, window a) exhibited no variation in the expression profile regardless of the habituation status. The differential accumulation of a number of small proteins was noted in PhI calli (Fig. $1 \mathrm{~A}-\mathrm{C}$, window b). Unlike the PhI callus cultures, other small groups of proteins were reproducibly expressed in both cytokinin- and auxin-habituated calli (Fig. $1 \mathrm{D}$ and $\mathrm{F}$, window $\mathrm{d}$ and e, respectively). Interestingly, two other groups (Fig. 1 D-F, window $f$ and c) displayed significant changes in their expression levels in habituated calluses compared with the control. Comparative analyses of both proteome maps seem to be more complex for cytokinin-habituated cell culture. These results indicate profound metabolic transformation of these types of tissues. Auxin and cytokinin play a critical role in regulation of both the proliferation and

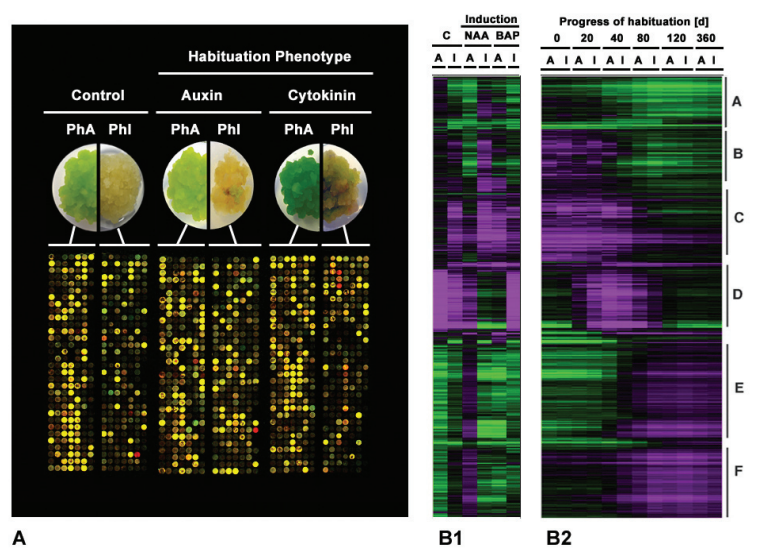

Fig. 2. Expression microarray profiling of habituated grapevine calluses (A - global microarray profile of control and hormone habituated cell cultures. The B1 heat map shows protein expression levels. B2 heat maps show the change of protein levels related to the progression of habituation. A - photosynthetically active calluses, I - photosynthetically inactive calluses, C - control. The six (A-F) functional groups of proteins are indicated on the right of the microarray profile)

differentiation of plant cells (Meins 1982). Habituation for these growth factors in plant culture provides an experimental system ideally suited for studying how the production of these factors affects metabolic pathways in cell organization.

\section{Microarray analysis}

Global picture of protein expression during the habituation was obtained by using the HTP-microarray system. The examined proteome profiles of non-habituated and/or habituated grapevine cell cultures depicted in Figure 2 B1 and 2 B2, show different microarray patterns. These specific patterns of tested cultures corresponded with different levels of expression of individual proteins generated as the habituation process progressed. Figure 2 B 2 shows dynamical changes in expression profiles of habituated tissues. It was observed that $360 \mathrm{~d}$ after planting calli on the hormonefree medium the expression profile of both $\mathrm{PhA}$ and PhI cultures was significantly changed and the proteins expressed were grouped into six functional clusters, termed herein as A-F clusters (Fig. 2 B2).

\section{Alkalinization}

Potential of MeJA to induce alkalinization in cultured cells was used for detecting and monitoring changes in cultures of habituated grapevine cells. 
Treatment of grapevine cells suspension with MeJA from the extracellular medium.

in concentration range $0-50 \mu \mathrm{M}$ is shown in Figure 3.

The addition of MeJA to grapevine cells triggered After addition of MeJA in concentration of $50 \mu \mathrm{M}$ to the extracellular $\mathrm{pH}$ changes relatively fast. Incubation grapevine cells, marked decrease of $\mathrm{pH}$ was recorded and consequently typical response of alkalinization of non-habituated PhA cells (Fig. $3 \mathrm{~A}$ ) with $50 \mu \mathrm{M}$ conobserved in cell suspension caused by influx protons centration of elicitor increased extracellular $\mathrm{pH}$ nearly by 0.50 units within $60 \mathrm{~min}$, whereas addition of 50
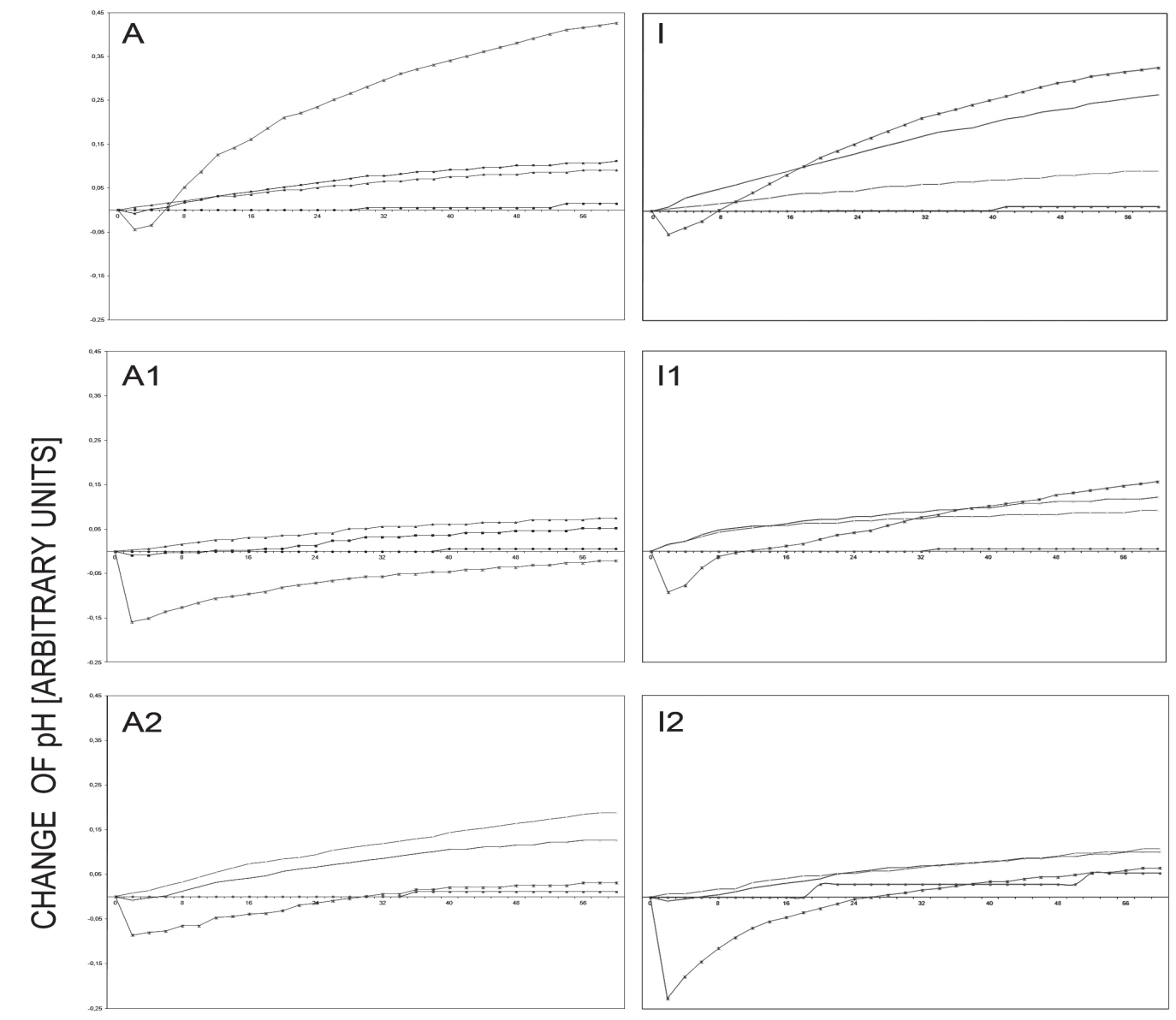

A3

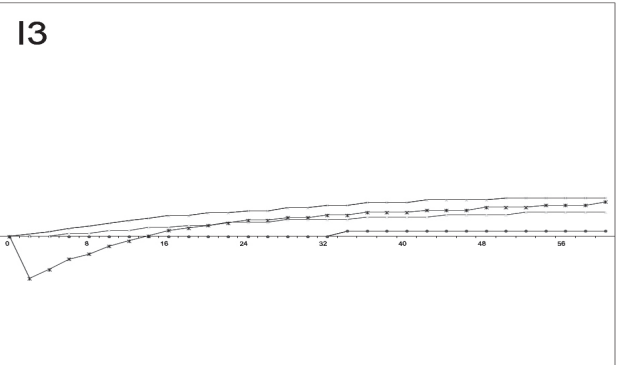

TIME [min]

Fig. 3. Effect of MeJA pre-treatment on extracellular alkalinization response in grapevine cell suspension culture A - photosynthetically active non-habituated cells, A1 - hormone-less, A2 - auxin-habituated, A3 - cytokinin-habituated cultures I - photosynthetically inactive non-habituated cells, I1 - hormone-less, I2 - auxin-habituated, I3 - cytokininhabituated cultures. Control/non-habituated - full circles (black), $0.5 \mu \mathrm{M}$ MeJA-triangles (green), $5 \mu \mathrm{M}$ MeJA-squares (blue), $50 \mu \mathrm{M}$ MeJA-stars (red) 
$\mu \mathrm{M}$ MeJA to non-habituated PhI cells (Fig. 3 I) leads to an increase in the extracellular $\mathrm{pH}$ of just about 0.35 units. When comparing the $\mathrm{pH}$ change after addition of $5 \mu \mathrm{M}$ of elicitor, there was a 0.15 units difference between PhA and PhI control cells (Fig. 3).

Treatment of habituated cell suspensions with MeJA in a concentration range of $0.5-50 \mu \mathrm{M}$, shown in Fig.
3 A $1-\mathrm{A} 3$ and $\mathrm{I} 1-\mathrm{I} 3$, reveal $\mathrm{pH}$ changes of different habituated PhA and PhI cells, which did not show significant modifications during the $60 \mathrm{~min}$ of treatment in comparison with each other. After challenge of $\mathrm{PhA}$ habituated cells with 0.5 and $5 \mu \mathrm{M}$ of elicitor there was a slight decrease of $\mathrm{pH}$ compared to the control, except for the auxin-habituated cells which showed an
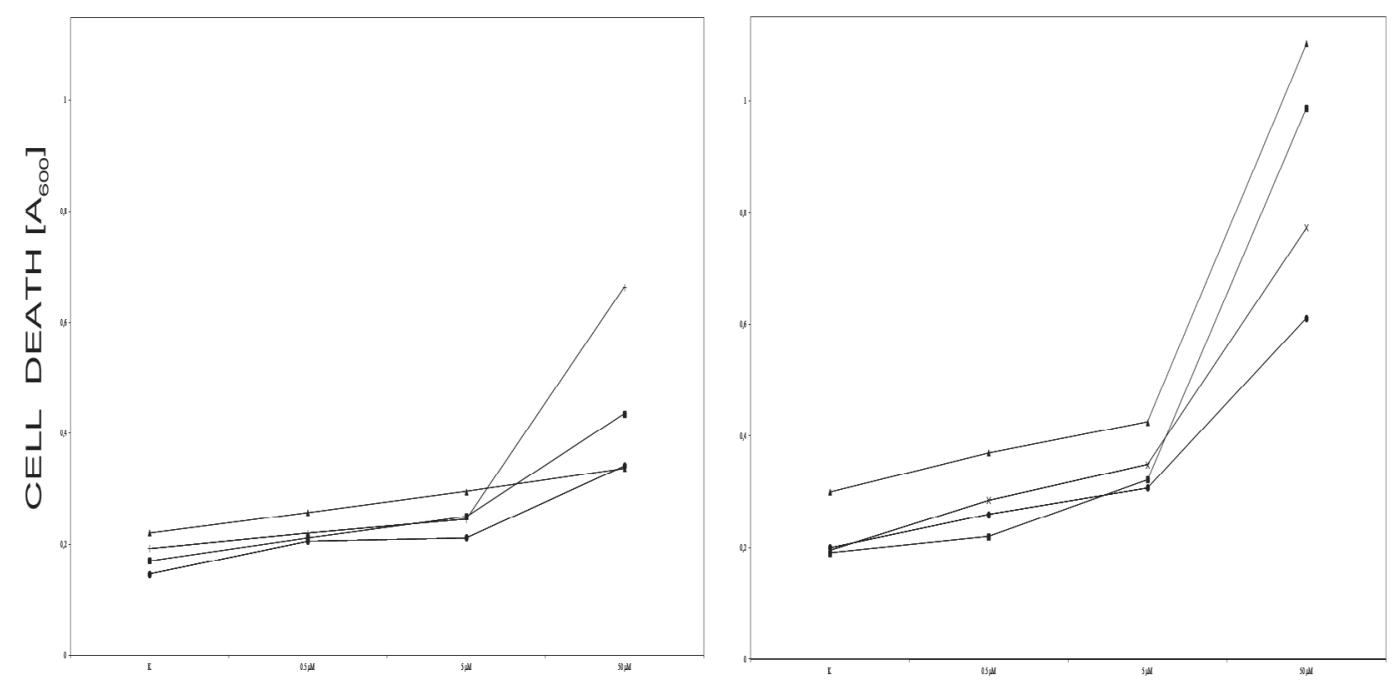

Fig. 4. Response for MeJA induction of cell death. Control/non-habituated-circles (black), hormone-less- squares (red), auxinhabituated- triangle (green), cytokinin-habituated- stars (blue)

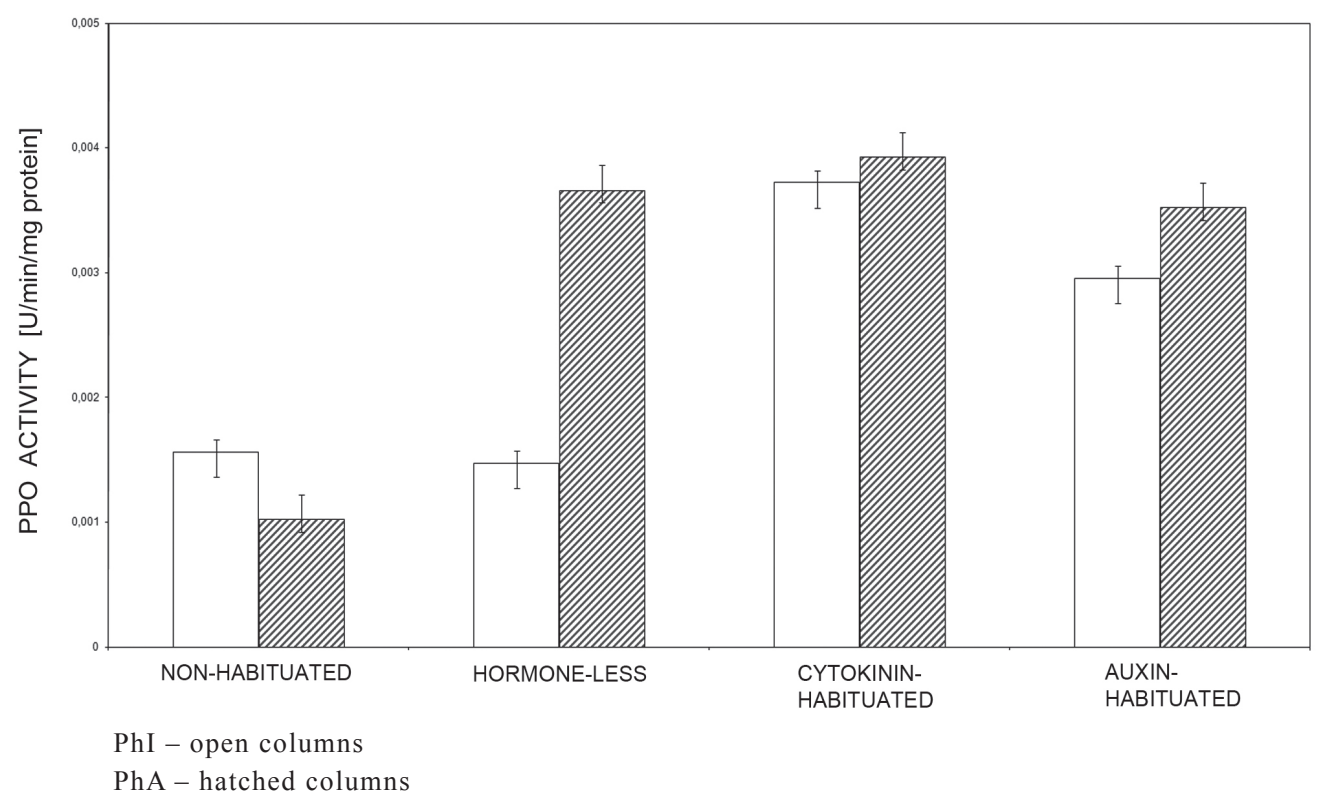

Fig. 5. Comparison of PPO activity in grapevine cell cultures 
increase in the value of alkalinization in concentration of $0.5 \mu \mathrm{M}$ MeJA compared with control. When comparing the $50 \mu \mathrm{M}$ elicitor concentration, there was a significant difference between control/non-habituated cells and habituated ones (Fig. 3). The major difference between these two types of cells is probably caused by higher depolarisation of the plasma membrane, loss of $\mathrm{K}^{+}, \mathrm{Ca}^{2+}$ influx followed by oxidative stress end eventually cell death. Also there is a well-known effect caused by hormonal regulation that reflect the activation of outwardly and inwardly rectifying $\mathrm{K}^{+}$channels at the plasma membrane by decreasing or increasing the cytoplasmic $\mathrm{pH}$ (Roos et al. 2006). It could mean that some unique metabolic features of control cells in comparison to habituated cells have increased their capacity for control of cytoplasmic $\mathrm{pH}$, especially the compensation of high acidity.

\section{Cell death}

Addition of MeJA in the range of concentrations $0.5-50 \mu \mathrm{M}$ induced cell death in a concentration dependent manner (Fig. 4). The two lowest concentrations of MeJA lightly stimulated cell death, while the highest concentration had a significant effect. Only in the highest concentration of MeJA applied to cells the cell death could be recognized by visual changes in habituated and non-habituated cells. Cell death values in $\mathrm{PhI}$ habituated cells show higher increase compared to $\mathrm{PhA}$ ones. The PhA cytokinin-habituated cells revealed increase of cell death by 0.3 units, in comparison to $\mathrm{PhA}$ auxin-habituated cells and the control. The MeJA stimulated cell death was most notable in the amount of auxin-habituated $\mathrm{PhI}$ cells.

\section{PPO activity}

PPO is a defense mechanism activated when the plant is exposed to a stress (Yang et al. 2011). The effect of PPO activity in control/non-habituated cells and hormonally habituated grapevine cell cultures is shown in Figure 5. From the results obtained it is evident that changes in measured PPO activity were hormonally dependent. Either the cytokinin- or auxin-habituated cell cultures have about two-fold higher PPO activity then the control/non-habituated and/or hormoneless PhI ones. Quite different pattern of PPO activity was observed for PhA cultures. In this case, the PPO activity seems to be not affected by hormonal regulation. Therefore it is clear, that the synthesis of PPO and its transport to chloroplasts, where plant PPOs are thought to be located, is a complex process, but which has the general features of import of nuclear coded proteins into sub-cellular organelles (Camacho-Cristobal et al. 2002). There is also evidence that boron (B) is one of the nutrients responsible for the changes in concentration and metabolism of phenolic compounds in vascular plants, since it is well known that B deficiency causes an accumulation of phenolic compounds and increase in polyphenoloxidase activity (Cakmak \& Römheld 1997). These ranges in PPO activity may reflect different metabolic states of either cell cultures. Since these results represent only preliminary observations, a further research effort is needed.

\section{CONCLUSIONS}

Proteome profiling showed that expression pattern in both types of studied callus cultures was altered due to different metabolic state of 55 proteins. Subsequent microarray profiling proved that these specific patterns of tested cultures corresponded with different expression level of individual proteins correlated with the progression of the habituation process.

There was a significant difference between control/ non-habituated cells and habituated ones, when extracellular alkalinization and cell death was studied at the $50 \mu \mathrm{M}$ concentration level of used elicitor.

For comparison of the defense response of habituated and non-habituated cultures, MeJA was chosen for its ability to trigger oxidative stress and hypersensitive response.

Finally, measurement of PPO activity confirmed that hormonal regulation of grapevine cell cultures significantly affects the metabolic pathways of this enzyme responsible for polyphenol oxidation.

Acknowledgement. This research was supported by a grant of the Slovak Ministry of Agriculture, contract No. 375/2010-510-K.

\section{REFERENCES}

BOSTOCK, R.M. 2005. Signal crosstalk and induced resistance: straddling the line between cost and benefit. In $\mathrm{An}$ nual Review of Phytopatholy, vol. 43, 2005, pp. 545-580, DOI: 10.1146/annurev.phyto.41.052002.095505.

BRADFORD, M.M. 1976. A rapid and sensitive method for 
the quantitation of microgram quantities of protein utilizing the principle of protein-dye binding. In Analytical Biochemistry, vol. 72, 1976, no.1-2, pp. 248-254, DOI: 10.1016/0003-2697(76)90527-3.

CAKMAK, I. - RÖMHELD, V. 1997. Boron deficiency-induced impairments of cellular functions in plants. In Plant Soil, vol. 193, 1997, no. 1-2, pp. 71-83.

CAMACHO-CRISTOBAL, J.J. - ANZELlOTTI, D. - GONZALEZ-FONTES, A. 2002. Changes in phenolic metabolism of tobacco plants during short-term boron deficiency. In Plant Physiology and Biochemistry, vol. 40, 2002, no. 12, pp. 997-1002.

CONSTABEL, C.P. - RYAN, C.A. 1998. A survey of woundand methyl jasmonate-induced leaf polyphenol oxidase in crop plants. In Phytochemistry, vol. 47, 1998, no. 4, pp. 507-511, DOI: 10.1016/S0031-9422(97)00539-6.

CONSTABEL, C.P. - BERGEY, D.R. - RYAN, C.A. 1995. System in activates synthesis of wound inducible tomato leaf polyphenol oxidase via the octadecanoid defense signaling pathway. In Proceedings of the National Academy of Science of the United States of Amerika, vol. 92, 1995, no. 2, pp. 407-411.

DUBERY, I.A. - TEODORCZUK, L.G. - LOUW, A. 2000. Early response in methyl jasmonate-preconditioned cells toward pathogen-derived elicitors. In Molecular Cell Biology Research Communications, vol. 3, 2000, no. 2, pp 105-110, DOI: 10.1006/mcbr.2000.0198.

EICHLER, E.E. - SANKOFF, D. 2003. Structural dynamics of eukaryotic chromosome evolution. In Science, vol. 301 2003, no. 5634, pp. 793-797.

FELTON, G.W. - KORTH, K.L. - BI, J.L. - WESLEY, S.V. - HUHMAN, D.V. - MATHEWS, M.C. - MURPHY, J.B - LAMB, C. - DIXON, R.A. 1999. Inverse relationship between systemic resistance of plants to microorganisms and to insect herbivory. In Current Biology, vol. 9, 1999, no. 6, pp. 317-320, DOI: 10.1016/S0960-9822(99)80140-7.

GAMBORG, O.L. - MILlER, R.A. - OJIMA, K. 1968. Nutrient requirements of suspension cultures of soybean root cells. In Experimental Cell Research, vol. 50, 1968, no. 1, pp. 151-158.

MEINS, F. Jr. 1982. Habituation of cultured plant cells. In KAHL, G. - SCHELL, J.S. (Eds.): Molecular Biology of Plant Tumors. New York: Academic Press Inc., 1982. pp. 3-31, ISBN 0123943809.

MEINS, F. Jr. 1989. A biochemical switch model for cell-heritable variation in cytokinin requirement. In GOLDBERG, R. (Ed.): The molecular basis of Plant Development.
New York: Alan. R. Liss, Inc., 1989, pp. 13-24, ISBN 0845126911 .

MURASHIGE, T. - SKOOG, F. 1962. A revised medium for rapid growth and bioassays with tobacco tissue cultures. In Plant Physiology, vol. 15, 1962, no. 3, pp. 473-497.

RABILloud, T. - BRODARD, V. - PELTRE, G. - RIGHETTI, P.G. - ETTORI, C. 1992. Modified silver-staining for immobilized ph gradients. In Electrophoresis, vol. 13, 1992, no. 4, pp. 264-266.

REPKA, V. 2001. Elicitor-stimulated induction of defense mechanisms and defense gene activation in grapevine cell suspension cultures. In Biologia Plantarum, vol. 44, 2001, no. 4, pp. 555-565.

REPKA, V. 2006. Early defense responses induced by two distinct elicitors derived from a Botrytis cinerea in grapevine leaves and cell suspensions. In Biologia Plantarum, vol. 50, 2006, no. 1, pp. 94-106.

REPKA, V. - BAUMGARTNEROVÁ, I. 2008. Grapevine habituation: Understanding of factors that contribute to neoplastic transformation and somaclonal variation. In Acta Agronomica Hungarica, vol. 56, 2008, no. 4, pp. 339409.

REPKA, V. - KUBÍKOVÁ, J. - FISHEROVÁ, I. 2000. Immunodetection of PR-1-like proteins in grapevine leaves infected with Oidium tuckerii and in elicited suspension cell cultures. In Vitis, vol. 39, 2000, no. 3, pp. 123-127.

ROOS, W. - VIEHWEGER, K. - DORDSCHBAL, B. - SCHUMANN, B. - EVERS, S. - STEIGHARDT, J. SCHWARTZE, W. 2006. Intracellular pH signals in the induction of secondary pathways - The case of Eschscholzia californica. In Journal of Plant Physiology, vol. 163, 2006, no. 3, pp. 369-381, DOI: 10.1016/j.jplph.2005.11.012.

RUBIN, G.M. - ASHBURNER, M. - PRUESS, M. - OVERBEEK, R. 2000. Comparative genomic of the eukaryotes. In Science, vol. 287, 2000, no. 5461, pp. 2204-2215.

WONG, T.C. - LUH, B.S. - WHITAKER, J.R. 1971. Isolation and characterization of polyphenol oxidase isoenzyme of Clingstone peach. In Plant Physiology, vol. 48, 1971, no. 1, pp. 19-23.

YANG, H.R. - HONG, K.T. - LIU, T. - HUANG, E.D. 2011. Effect of salicylic acid on jasmonic acid-related defense response of pea seedlings to wounding. In Scientia Horticulturae, vol. 128, 2011, no. 3, pp. 166-173.

Received: May, 20th 2011 